\title{
Mediating the local: Representing Javanese cultures on local television in Indonesia
}

\author{
Els Bogaerts
}

The end of the New Order regime and the passing of new legislation in Indonesia offered the mushrooming local broadcasting industry ample opportunities. This article examines how the changing circumstances have enabled television stations to foreground local identities within a national frame of reference. It focuses on developments in local television in the Special Region of Yogyakarta, Central Java, between 1998 and 2009. Using various localising strategies, the stations provide a more diversified local content than was the case during the Soeharto period. The analysis is based on local resources and supported by inside information, generously provided by media workers and artists.

The political reforms in Indonesia since 1998 have altered the face of its televisionscape. ${ }^{1}$ After the far-reaching political changes following President Soeharto's resignation and the subsequent Reformasi era, reinforced by such new legislation as the Regional Autonomy Law, which awakened a renewed consciousness of local/regional identity, and the new Broadcasting Law, an entirely new local broadcasting industry was created. Although the new broadcasting legislation did not specify a definition of 'local', an exercise also never previously undertaken, it was the television industry itself that defined what this epithet meant in its broadcasts. Defining, celebrating and defending the local has become the stuff of innumerable newspaper articles and editorials, seminars, television talk shows and neighbourhood conversations. ${ }^{2}$ In short, the concept of the local has taken an increasing hold on people's consciousness in Indonesia.

To illustrate this change, this article tackles representations of Javanese cultures within the constraints of and opportunities offered by the new local broadcasting

Els Bogaerts is a Researcher at the Leiden Institute of Area Studies, Leiden University. Correspondence in connection with this article should be addressed to: bogaerte@xs4all.nl. The author would like to thank: the Asia Research Institute, National University of Singapore, for the opportunity to present an earlier version of this article at the 7th Asian Graduate Forum on Southeast Asian Studies (July 2012) and the subsidies; Nalin Mehta, panel chair, and the Forum participants for their input; Ben Arps, Tineke Hellwig, Victoria Clara van Groenendael, Rosemary Robson and the two anonymous JSEAS referees for their valuable comments and suggestions, and Cock Griffioen for her support; and the Leiden University Fund and the Leiden University Institute of Area Studies for sponsoring a short research visit to Indonesia in 2012.

1 Inspired by Arjun Appadurai's notion of a mediascape, in Modernity at large: Cultural dimensions of globalization (Minneapolis: University of Minnesota Press, 1998), p. 33.

2 Barbara Hatley, 'Global influence, national politics and local identity in Central Javanese theatre', Review of Indonesian and Malaysian Affairs 38, 2 (2004): 63. 
industries. I will focus on the televisionscape in the Special Region of Yogyakarta in Central Java between 1998 and 2009, and on programmes in the regional language, Javanese, rather than the national language, Indonesian. Some insight into the regulation of local broadcasting is indispensable in pinpointing the relevant issues. I will concentrate on the localising strategies of Jogja TV, which was set up in 2004, and relate them to the practices of TVRI Jogja (formerly called TVRI Stasiun Yogyakarta, a regional station of Televisi Republik Indonesia), which has been broadcasting local productions since 1965. In this search for the local I will pay special attention to language use.

The first point I would like to make is that the concept of 'the local' acquires meaning in the mediating practices of local television stations. My second point is that, despite and because of their commercial interests, local television stations now give a much more diversified representation of Javanese identities in their programmes compared to past practices. My third argument concerns the new regulations that are implemented pragmatically to suit the interests of the television industry. I will commence by reflecting on the concept of the local.

\section{Looking into the local}

The end of the twentieth century saw a breakthrough, a heightened awareness of local identity [as] fostered by regional autonomy and by the ideology of participatory democracy', as Barbara Hatley observes. ${ }^{3}$ Under the New Order (1966-1998), the development of a national Indonesian identity and unity had been extensively promoted by the government and national television. In the post-Soeharto era, this construct of 'the national' remains an important frame of reference. Ethnic identity - according to the mental map propagated by the New Order government was confined to distinct geographical areas, the daerah (regions). Consequently, the Javanese were imagined as living in the regions of Central and East Java and the Special Region of Yogyakarta. But other areas densely populated by Javanese (such as Jakarta, Bandung, and Lampung in South Sumatra) as well as other ethnic populations in what were called Javanese regions were erased from this mental map. The idea of Java (and the other Indonesian regions) as 'a single comprehensible entity $^{4}$ with a homogeneous Javanese culture also ignored the various Javanese subcultures and identities.

In the context of Indonesian television, the local emerges as a multifaceted concept. As a category of legislative practice, the local is used in the Indonesian Broadcasting Law as one of the markers defining and regulating broadcasting. I will return to this issue when I discuss the regulation of local broadcasting.

What is categorised as local in domestic programming is often actually national, meaning it is in the national language [...] and its content is designed to be

3 Barbara Hatley, 'Indonesian theatre ten years after Reformasi', Journal of Indonesian Social Sciences and Humanities 1 (2008): 53.

4 Hans Antlöv and Jörgen Hellman, 'Introduction: Images of Java in academic discourses', in The Java that never was: Academic theories and political practices, ed. Hans Antlöv and Jörgen Hellman (Münster: LIT, 2005), p. 4. 
acceptable to all its culturally varied audiences'. ${ }^{5}$ Hence, localising often means adapting foreign formats to the Indonesian context on a national level, as discussed by Philip Kitley and Penelope Coutas. ${ }^{6}$ But the concept can also refer to the local/regional - meaning subnational, regional or subregional. I will use the term localising in the sense of Yogyakarta's television stations adapting their programmes to the cultural circumstances of this locus and to what they imagine meets the wishes and needs of their target audiences.

To discover how broadcasters design their programmes 'so as to relate to their audiences in specific, inclusive, and cooperative ways', I have principally based my analysis on a study of television broadcasts and the industry's self-identifying practices. I have related these to Indonesian legislative texts, articles and essays published in Indonesian newspapers and magazines, programme descriptions and broadcast schedules. Furthermore, I interviewed local media practitioners and performing artists and attended the recording and production of various television programmes.

\section{Studying televised local culture in Indonesia}

Earlier publications on television in Indonesia have focused on the active and prominent role of this medium in nation building. ${ }^{8}$ In their standard works, Kitley and Krishna Sen and David Hill paved the way for further research, as did the work of Drew McDaniel. ${ }^{9}$

This article fits in with more recent publications presenting studies of specific local cultural expressions on Indonesian television that are tied to a locality, a specific group of people and/or a language at the subnational level. Edwin Jurriëns has discussed the interaction between the global and the local by putting the electronic media of West Java into the conceptual framework of travel and migrancy. ${ }^{10}$ In her study of the Betawi series Si Doel Anak Sekolahan, Klarijn Loven has explored various understandings of national television and analysed how the media in Indonesia 'both shape and are shaped by discourse in society at large'. ${ }^{11}$ Elsewhere, Jan Mrázek

5 Krishna Sen and David T. Hill, Media, culture and politics in Indonesia (Melbourne: Oxford University Press, 2000), p. 123.

6 Philip Kitley, 'Closing the creativity gap - renting intellectual capital in the name of local content: Indonesia in the global television format business', in Television across Asia: Television industries, programme formats and globalization, ed. Albert Moran and Michael Keane (London: Routledge Curzon, 2004), pp. 138-55; Penelope Coutas, 'Fame, fortune, Fantasi: Indonesian Idol and the new celebrity', Asian Journal of Communication 16, 4 (2006): 371-92.

7 Ian Hutchby, Media talk: Conversation analysis and the study of broadcasting (Maidenhead: Open University Press, 2006), pp. 10-12; emphasis in the original.

8 Satellite TV in Indonesia, ed. Alfian and Godwin C. Chu (Honolulu: East-West Center and LEKNAS/LIPI, 1981); Godwin C. Chu, Alfian and Wilbur Schramm, Social impact of satellite television in rural Indonesia (Singapore: Asian Mass Communication Research and Information Centre, 1991).

9 Philip Kitley, Television, nation, and culture in Indonesia (Athens: Ohio University Center for International Studies, 2000); Sen and Hill, Media, culture and politics; Drew O. McDaniel, Broadcasting in the Malay world: Radio, television and video in Brunei, Indonesia, Malaysia, and Singapore (Norwood, NJ: Ablex, 1994); Drew O. McDaniel, Electronic tigers of Southeast Asia: The politics of media, technology, and national development (Ames: Iowa State University Press, 2002).

10 Edwin Jurriëns, Cultural travel and migrancy: The artistic representation of globalization in the electronic media of West Java (Leiden: KITLV Press, 2004).

11 Klarijn Loven, Watching Si Doel: Television, language, and cultural identity in contemporary Indonesia (Leiden: KITLV Press, 2008). 
dissected the clown scenes to discuss innovation in televised wayang kulit (shadow puppet theatre) performances in relation to the contemporary world. Focusing on the Surabayan Pojok Kampung, a news programme in the local dialect, Bernard Arps has shown that the language use in the programme differs significantly from New Order conventions. ${ }^{12}$ Other relevant perspectives on local television in Indonesia include indigenous audience responses to televisual representations of Balinese culture in Marc Hobart's research, and Rachmah Ida's examination of ownership and power in local media. ${ }^{13}$ The present study has also been enriched by comparative perspectives such as those by Ping-Hung Chen on domestication strategies in Taiwan, and the contributors to a special issue of Media History in 2010 about 'localizing the transnational in regional television in Europe. ${ }^{14}$

\section{A new local broadcasting industry}

Television may be an industry of cut-throat competition, but local businesspeople aren't afraid to invest in new stations. Two privately run TV stations - RB TV and Jogja TV were established this month, with Tugu TV to follow next month. The three stations are confident they can capture the hearts of Yogyakartans, with down-to-earth programs and news on Yogyakarta and its vicinity.

These sentences open an article by Slamet Susanto in the Jakarta Post in September $2004,{ }^{15}$ which went on to present new developments in the Yogyakarta mediascape, touching upon the increasing complexity of the local television world. The new Jogja TV station was established by GBPH Prabukusumo, the brother of Yogyakarta's governor and reigning sultan, Hamengkubuwono X. Therefore it automatically had a privileged, influential connection to the kraton (the royal palace), its capital and prestige, and the prince's personal business networks. Although the article does not acknowledge the active role that the director of Bali TV, Satria Naradha, and the Bali Post network played in the founding of Jogja TV, ${ }^{16}$ it does mention that Bali TV, 'which also focuses on local traditions and culture in its shows' was going to 'train employees and produce joint programs'. Nor does it refer to Jogja TV’s board member

12 Jan Mrázek, 'Javanese wayang kulit in the times of comedy: Clown scenes, innovation, and the performance's being in the present world', Part One, Indonesia 68 (Oct. 1999): 39-128, and Part Two, Indonesia 69 (Apr. 2000): 107-72; Bernard Arps and Katinka van Heeren, 'Ghosthunting and vulgar news: Popular realities on recent Indonesian television', in Indonesian transitions, ed. Henk Schulte Nordholt (Yogyakarta: Pustaka Pelajar, 2006), p. 315.

13 Mark Hobart, 'Drunk on the screen: Balinese conversations about television and advertising', in Asian media productions, ed. Brian Moeran (Honolulu: University of Hawaii Press, 2001), pp. 197219; Mark Hobart, 'Live or dead? Televising theater in Bali', in Media worlds: Anthropology on new terrain, ed. Faye D. Ginsburg, Lila Abu-Lughod and Brian Larkin (Berkeley: University of California Press, 2002), pp. 370-82; Rachmah Ida, 'Reorganisation of media power in post-authoritarian Indonesia: Ownership, power and influence of local media entrepreneurs', in Politics and the media in twenty-first century Indonesia: Decade of democracy, ed. Krishna Sen and David Hill (London: Routledge, 2011), pp. 13-25.

14 Ping-Hung Chen, 'Transnational cable channels in the Taiwanese market: A study of domestication through programming strategies', Gazette 66, 2 (2004): 167-83; Catherine Johnson and Andreas Fickers, 'Roundtable: Perspectives on localizing the transnational in regional television history. Introduction', Media History 16, 1 (2010): 97-101.

15 Slamet Susanto, 'TV stations explore local traditions', Jakarta Post, 11 Sept. 2004.

16 Personal communication, Oka Kusumayudha, komisaris Jogja TV, on 13 Mar. 2009. 
Oka Kusumayudha's position as editor-in-chief of the Yogyakarta newspaper Kedaulatan Rakyat. The principal investor in the second new station discussed in the article, RB TV (Retjo Buntung TV), was the Retjo Buntung Group, a business network experienced in financing private radio stations in the province. The most popular of these is Radio Retjo Buntung, on air since March 1967.

Susanto's article also stated that both stations would try to establish close contacts with local enterprises and production houses as well as local audiences. Both Jogja TV and RB TV planned to focus on traditional topics and local news, countering the content of programmes broadcast by Jakarta-based stations, 'which mostly focus on city living rather than local culture'. These 'have proved unpopular here, as they aren't relevant to locals. They are also expensive to air.' RB TV had also invited the Voice of America and the German station Deutsche Welle to supply programmes.

The third new Yogyakartan station, Tugu TV, then in the planning stage, intended to target youths and tap into this segment of the audience and advertising markets. ${ }^{17}$ However, it never made it to air. In March 2012, RB TV began operating under the aegis of Kompas TV, a Jakarta-based station owned by the Kompas Gramedia group. In 2011, another local private TV station was launched, the religiously oriented ADI TV that is affiliated with the major Indonesian Muslim organisation, Muhammadiyah.

The Jakarta Post article also highlighted the main challenges and problems faced by television at the beginning of the twenty-first century. The local stations' greatest challenge were the competitive strategies employed by other stations aiming to tap into the same (local) market. In response, Jogja TV and RB TV, each presenting itself as the first local private station in Yogyakarta, were forced to carve a niche within the existing infrastructure of broadcasting institutions in the region. Earlier, besides the national and local TVRI stations, the public had only had access to a growing number of big private TV stations, which were then still broadcasting nation-wide, and to several global TV stations. It would after all take a decade for the 2002 Broadcasting Law - requiring all stations except TVRI to broadcast locally and cooperate with local networks - to be fully implemented. Local broadcasting institutions located elsewhere but explicitly targeting the ethnic Javanese inhabitants of Yogyakarta were another source of competition. One example is the Surakarta-based Terang Abadi Televisi (TATV), which positioned itself as a contemporary institution but remaining involved in culture.

\section{Trendsetters}

The establishment of two local television stations in Yogyakarta was the direct outcome of the new Regional Autonomy Law and the subsequent new Broadcasting Law. The first initiative to establish a local television station in Java, in which Jawa Pos Media Televisi (JTV) set the trend, was taken in Surabaya in 2001. JTV was designed to be a 'local television station with a metropolitan air', ${ }^{18}$ absolutely determined not to

17 Slamet Susanto, 'TV stations explore local traditions'.

18 'Televisi lokal bernuansa metropolis'; Nugroho Dewanto et al., 'Semangat daerah membangun TV lokal' [Regional spirit builds local TV], Tempo Online, 28 May 2001. 
yield to the national commercial broadcasting institutions. Armed with its tagline 'Satus Persen Jatim' (a hundred per cent East Java), to forge stronger ties to Surabayan society, especially its middle and lower classes, from its launch JTV emphasised local content, preferring live and interactive formats, bolstered by off-air activities. JTV broadcasts in Indonesian and in Javanese. Unquestionably, the use of the Surabaya dialect in specific programmes has contributed to its popularity, but it has also elicited severe criticism.

The model for other local private stations such as Jogja TV was Bali TV, which was launched in May 2002. Bali TV targets potential audiences of Balinese, non-Balinese and non-Indonesian origin; Hinduism, the representation of Balinese traditional culture (as constructed by Bali TV) in contemporary Bali, and the Balinese language play a prominent role in its programming. The station does not ignore Indonesian identity, employing national symbols and broadcasting some programmes in Indonesian. Various programmes and commercials in foreign languages target the resident expat community and tourists and visitors. ${ }^{19}$

Like JTV and Bali TV, Jogja TV is a member of larger media networks. JTV is part of the Jawa Pos network; Bali TV and Jogja TV of the Bali Post Media Group. In all cases, this branding is determined by addressing and representing local identity; an identity that has been (re-)constructed by the television stations themselves. The television stations claim they are preserving traditional local cultures while being a link to contemporary trends. They also encompass Indonesian national identity by various means and broadcast imported programmes with foreign content.

\section{Countering monopolies}

The establishment of local private stations all over the country is linked to the post-Soeharto move towards democratisation, deconcentration and decentralisation. For more than twenty-five years, until the appearance in the late 1980s of the first private stations owned by President Soeharto's family members and cronies, the government-controlled TVRI had been the sole broadcaster. Thereafter, the television industry was dominated by these Jakarta-based private media. Even when five new broadcasting permits were issued by President Habibie in 1999, 'as such diversifying both the television landscape and patterns of ownership', ${ }^{20}$ and cable television had been introduced, ${ }^{21}$ the grip of the 'Jakartan' hegemony did not slacken. By monopolising both media ownership and content, using a restricted number of (cheap) formats, often based on imported ones, and disseminating fairly uniform information, it was said that the television stations and their products did not represent Indonesia's cultural diversity. Sen and Hill argue that 'with the exception of radio, all regional cultures (even that of the pre-eminent ethnic group) effectively had only minority status in the national culture industries'. ${ }^{22}$

To break this monopoly and enforce diversity of content and ownership, people insisted on a reorganisation of the industry. Inspired by the post-Soeharto spirit of Reformasi, ${ }^{23}$ idealistic intellectuals, artists, media practitioners and specialists, and

19 See www.balitv.tv (last accessed May 2014).

20 Loven, Watching Si Doel, p. 329.

21 Sen and Hill, Media, culture, and politics, p. 132.

22 Ibid., p. 16.

23 Personal communications: Oka Kusumayudha (Jogja TV); Sunardian Wirodono (independent 
representatives of media organisations instigated this call for change. If their aims were to be achieved, serious competition between television stations would be essential. Certainly, audiences needed to be offered alternatives, enabling them to choose between more diversified kinds of news, information and entertainment, and to participate actively in the production and consumption of media products.

A new Broadcasting Law which prioritised local broadcasting provided the legal basis for the democratisation of the Indonesian televisionscape. Whereas the local had previously not been an issue - under the New Order the continuous focus was on the use of the national language and the construction of a national identity and national culture - the new era required a major shift in attention. This situation is not confined to Indonesia; comparative studies have indicated a relationship between global capitalism and rising concerns with the local as a site of resistance and liberation. ${ }^{24}$

\section{Regulating local broadcasting}

The Broadcasting Law of 2002, ${ }^{25}$ revised in 2007, differentiates between public, private and community broadcasting services and pay television. It defines the tasks, function and responsibilities, forms of organisation, ownership, and resources for each category. In this essay I concentrate on public and private broadcasting services.

Public broadcasting services are established by the state and are the only broadcasting services licensed to broadcast nationwide. They are supposedly independent, neutral and non-commercial in character, and provide services in the public interest. In the Special Region of Yogyakarta, public broadcasting is the responsibility of the centrally broadcasting Jakarta-based TVRI and the regional TVRI Jogja.

The local character of the private broadcasting services is defined in terms of capital, management and broadcasting area. The bulk of the starting capital and the administration and management of a local station should be in the hands of the local community. ${ }^{26}$ Their sphere of influence is limited as private broadcasting services are only licensed to broadcast to a restricted area, namely the area surrounding the location of the broadcasting service or the area of a regency or city. ${ }^{27}$ This means that the act of broadcasting itself should become local; what constitutes 'local' in each case is to be defined by the Indonesian Broadcasting Commission (Komisi Penyiaran Indonesia, KPI), in collaboration with the national government. ${ }^{28}$

Under the new law, the use of the national language - 'good, correct Indonesian' - both oral and written, is compulsory, except when broadcasting in regional or foreign languages. Regional vernaculars (bahasa daerah) can be used whenever the broadcast has local content and, when required, to support certain

media practitioner and specialist); Tri Suparyanto (Komisi Penyiaran Indonesia Daerah Yogyakarta); and Jimmy Silalahi (Asosiasi Televisi Lokal Indonesia, Jakarta), in Mar. 2009.

24 See for example, Arif Dirlik, 'The global in the local', in Global/local: Cultural production and the transnational imaginary, ed. Rob Wilson and Wimal Dissanayake (Durham: Duke University Press, 1996), p. 22.

25 Undang-Undang Republik Indonesia nomor 32 tentang penyiaran, 2002, http://ibau.bappenas.go. id/data/peraturan/Undang-Undang/UU\%20No.\%2032\%20Tahun\%202002\%20Penyiaran.pdf (last accessed May 2014) (hereafter UUP 32/2002).

26 UUP 32/2002, Pasal 31 (6).

27 Peraturan Pemerintah 50/2005 (hereafter PP 50/2005), Penjelasan atas Pasal 13.

28 UUP 32/2002, Pasal 18; PP 50/2005, Pasal 1 (4-5). 
programmes. ${ }^{29}$ Nevertheless, at least 60 per cent of the daily broadcasts by the private television stations should consist of Indonesian productions. ${ }^{30}$ The 2005 government regulation adds that the broadcasts should be local, meaning they should consist of local content (muatan lokal), ${ }^{31}$ without any further elucidation.

KPI was established to administer the requirements of the new Broadcasting Law, ${ }^{32}$ and was intended to bridge the interests of the people, the broadcasting institutions and the government. ${ }^{33}$ Its regulations designate local programmes as a separate media category, but nowhere has KPI identified what constitutes local content, beyond stating that broadcasting institutions should respect the norms and values of the religions and cultures of the multicultural peoples of Indonesia. ${ }^{34}$ Only in December 2009 did KPI revise the regulations; local programmes were defined as broadcasts with local content composed of events, issues, story backgrounds and human resources, to be used to develop the cultures and potential of the specific regions. ${ }^{35}$ This addendum did not really shed much light on the matter.

While the legislation and regulations remained vague about the meaning of local content, this issue was one of the main topics of public discourse around local television during the first decade of the twenty-first century. All parties with an interest in the establishment of local TV stations were involved, from local television managers to academics specialising in communication, journalists, producers and artists. In the discussions, the notion of kearifan lokal ('local wisdom'), frequently recurs. It encompasses the culture, tangible and intangible heritage, tradition, and shared knowledge of an ethnic group in a specific locality.

\section{Televising the local in Daerah Istimewa Yogyakarta}

The local broadcasting institutions in Yogyakarta, both public and private, have adopted several strategies to define themselves as local within the Indonesian televisionscape. By firmly linking their image to the region, broadcasting programmes in Javanese, localising foreign formats and productions, featuring local expressions of culture and establishing local alliances reinforced by off-air activities, their strategy has been to address local communities as potential audiences and advertisers.

\section{The local as branding: Citra Yogyakarta}

Both TVRI Jogja and the commercial television stations in Yogyakarta link themselves explicitly to the geographical locality and its inhabitants, utilising such concepts as tradition, local wisdom and regional language. They all maintain the long-standing,

29 When required, foreign-language programmes should be subtitled in Indonesian or dubbed. UUP 32/2002, Pasal 38 (1-2), and Pasal 39 (1, 2 and 3); PP 50/2005, Pasal 16 (1-6).

30 UUP 32/2002, Pasal 36; PP 50/2005, Pasal 14 (2).

31 PP 50/2005, Pasal 34 (5); Penjelasan atas Pasal 34 (5).

32 UUP 32/2002, Bab I Pasal 1 (13).

33 Peraturan Komisi Penyiaran Indonesia nomor 02 tahun 2007 dan nomor 03 tahun 2007 tentang pedoman perilaku penyiaran dan standar program siaran (hereafter Peraturan KPI 02/2007) (Yogyakarta: KPID Daerah Istimewa Yogyakarta, 2008), p. ii.

34 Peraturan KPI 02/2007, Bab II Pasal 4 c, p. 8.

35 Peraturan Komisi Penyiaran Indonesia nomor 02/P/KPI/12/2009 tentang pedoman perilaku penyiaran (P3) dan standar program siaran (SPS), Bab I Pasal 1 (12), http://www.kpi.go. id/download/regulasi/P3-SPS_2009.pdf (last accessed May 2014). 
idealised citra (image) of Yogyakarta, consisting of well-known local and national identity markers. The city is perceived as an icon of education (because of the presence of Gadjah Mada University and many other educational institutes that attract students and academics from all over Indonesia and abroad); of culture (because of the kraton as 'the centre of Javanese culture', and the wealth of artistic and cultural activities in the city); and of tourism. The city's role during the independence struggle, when Yogyakarta was the Republic's capital, still lends it a special aura. This idea of Yogyakarta as an imagined community and lieu de mémoire is constructed on its tangible and intangible heritage, pivoted upon a glorious past and its legacies as well as contemporary issues. ${ }^{36}$ It is worth noting here that this image is not a recent creation and had been used by TVRI Stasiun Yogyakarta during the New Order.

Every television station in the region claims a specific identity, to differentiate itself from the others. Consequently, Jogja TV claims to use contemporary technologies, without disregarding local classic traditions. Standing resolutely behind its slogan 'Never-ending tradition' (Tradisi tiada henti), Jogja TV has made local content its most important asset and culture its 'star attraction'. ${ }^{37}$

TVRI Jogja is another story. Founded in 1965 as TVRI Stasiun Yogyakarta, it was meant to develop culturally diverse programmes for local audiences. However, the October 1965 coup which ushered in the New Order made it dependent on the national TVRI station. ${ }^{38}$ In the post-Soeharto era, for many years the national station itself struggled in its paradoxical situation compounded by a combination of incompatible tasks, requirements and facts.

In 2005, when the government decided on TVRI's status as a public broadcasting service, ${ }^{39}$ TVRI was redirected to its original purpose. The Indonesian public would become both the starting-point and the final objective of its broadcasts. This would mark it out from the private broadcasting services. ${ }^{40}$ Although its new status offered TVRI Jogja opportunities, it did not solve its financial problems, because the station now also had to compete with local commercial broadcasters. Under the slogan announcing TVRI Jogja as 'our public medium' (TVRI Jogja media publik kita), the station planned to focus on culture, educating its audiences in a more balanced way rather than just entertaining them. It established a close relationship with the public in all locations and among all social classes, and was non-commercial to boot. Conscious of its branding, just as in the past, it continuously reconfirmed its strong link to the Special Region of Yogyakarta. Before the changes, the station had been popular for its broadcasts of such specifically Javanese performances as wayang

36 Benedict Anderson, Imagined communities: Reflections on the origin and spread of nationalism, rev. ed. (London: Verso, 2006); Pierre Nora, Les lieux de mémoire (Paris: Gallimard, 1984-92).

37 Mawar Kusuma, 'Jogja TV: Tradisi tiada henti, idealisme yang terbukti' [Jogja TV: Never-ending tradition, proven idealism]', Kompas, 31 Oct. 2007.

38 Philip Kitley, 'Civil society in charge? Television and the public sphere in Indonesia after Reformasi', in Television, regulation and civil society in Asia, ed. Philip Kitley (London: RoutledgeCurzon, 2003), p. 98 .

39 The Peraturan Pemerintah nomor 13/2005, a government regulation, reconfirmed this decision taken in the 2002 Broadcasting Law.

40 Arswendo Atmowiloto, 'TVRI dan ketahanan budaya nasional' [TVRI and the perseverance of national culture], Koran Tempo, 26 July 2006. 
kulit (shadow puppetry) and kethoprak (a popular drama form), and other genres considered typical representations of Yogyakartan Javanese identity. In its new context, it sought innovative possibilities to expand the concept of muatan lokal and did its utmost to keep the old successes going. Now free from the constraints of having to be a mouthpiece for national government policies, TVRI Jogja looked for new, local partners.

Not surprisingly, local icons are often used in the branding of local television stations. They are highly visible in the stations' identifiers and in the leaders of programmes featuring local content. The images and sounds conveying this construct represent historical, cultural and natural landmarks, important events and ceremonies, and Central Javanese gamelan music. Consequently, TVRI Jogja and Jogja TV differ from each other only in the selection and editing of these icons, but not in the way they represent the locale and link themselves to this representation.

Despite this shift in emphasis, the nation remains 'an important unit of representation, legislation, and collective address'. ${ }^{41}$ Although representing expressions of Javanese identity and addressing ethnic Javanese audiences in (part of) their programming, the larger frame of reference of the local broadcasters is Indonesia, their main medium of communication the national language, Indonesian. Even in Javanese broadcasts this hovers in the background.

\section{Localising global formats}

As in many other countries, established media formats such as news programmes, talk shows, foreign film productions and advertisements were adopted along with television technology and localised, that is, Indonesianised. Their wholesale adoption introduced the global as yet another larger frame of reference alongside the national. Later, local television stations adapted these global formats to the regional/local circumstances. In Yogyakarta this meant that some of the formats were Javanised and provided with Yogyakartan identity markers.

\section{News programmes}

One strategy is to focus on local news, a crucial element in the construction of regional audiences. ${ }^{42}$ In their tracking of the indigenisation processes of Asian television programming, Joseph Chan and Eric Ma signal local television news as the basis of national consensus and solidarity. ${ }^{43}$ Indonesia is no exception. Here, local should be read as domestic, national. As mentioned, until the late 1990s, the production and dissemination of news in Indonesia was controlled by the government. The transmission of the national TVRI news was compulsory for all television stations and only some local radio stations broadcast the news in local vernaculars. For commercial

41 William Mazzarella, 'Culture, globalization, mediation', Annual Review of Anthropology 33 (2004): 352.

42 Johnson and Fickers, 'Roundtable: Perspectives', p. 100.

43 Joseph Man Chan and Eric K.W. Ma, 'Asian television: Global trends and local processes', International Communication Gazette 58 (1996): 51. 
reasons, from their inception the private broadcasters experimented on the fringes ${ }^{44}$ of the state monopoly and claimed some of the news space by broadcasting alternative bulletins, initially focusing on soft news and human interest stories. As this sort of news bulletin was also presented in Indonesian, programmes featuring local news from a local point of view and presented in Javanese were a novelty. In this case, local should be read as a subnational geographical and cultural space.

Local news programmes observed during the study period reported on regional events, running the gamut of political events, the local economy (a good cacao harvest, rising rice prices), natural disasters, crime, cultural performances and exhibitions, and social and religious events such as weddings or circumcision ceremonies. These topics are presented in an adaptation of the standard global news format, consisting of a studio presentation of the themes, followed by more detailed coverage. Attention is paid to each item in visual footage, shot in a locale, accompanied by a voice-over by a local reporter, sometimes including an interview with a relevant official, specialist or person involved in the topic concerned. In private television broadcasts, news sequences are alternated with commercial breaks. TVRI Jogja announces its commercial sponsors at the end of the programme; both also show advertisements in running texts, but here the similarity ends. The style of presentation and language use differ according to the station and the programme, which leads aptly to the importance of the local vernacular.

As speakers of Javanese value the correct observance of language etiquette highly, several considerations had to be weighed up when deciding on the 'mode of direct address' 45 to be used in Javanese news bulletins. As Andrew Tolson states, identities are ascribed to audiences in the ways they are addressed. ${ }^{46}$ To keep the audiences watching, he explains that 'the onus is then on broadcasters to speak to us in ways we want to be spoken to, in ways which enhance our domestic environments and do not detract from them'. ${ }^{47}$ Hence TV stations have to meticulously assess which register best meets their viewers' expectations. The controversy caused by the use of the Surabayan dialect in Pojok Kampung, a news programme broadcast by the aforementioned JTV Surabaya, is an excellent illustration of the significance and impact of language choice in a news programme. Linguistic etiquette was the critical factor that elicited praise or criticism from audiences, ${ }^{48}$ and in particular the coarseness or even offensiveness of its language' was commented upon. ${ }^{49}$

The Javanese language consists of a complicated system of rules and conventions through which speakers express degrees of politeness, courtesy, respect or appreciation to the person(s) being addressed or referred to: ${ }^{50}$ ngoko is used in a familiar

44 Kukuh Sanyoto, 'Indonesian television and the dynamics of transition', in Media fortunes, changing times: ASEAN states in transition, ed. Russell Heng (Singapore: Institute of Southeast Asian Studies, 2002), p. 88.

45 Andrew Tolson, Media talk: Spoken discourse on TV and radio (Edinburgh: Edinburgh University Press, 2006), p. 7.

46 Ibid., p. 16.

47 Ibid., p. 8.

48 Arps and Van Heeren, 'Ghosthunting and vulgar news', p. 309.

49 Ibid., p. 313.

50 Ben Arps, Els Bogaerts, Willem van der Molen, Ignatius Supriyanto en Jan van den Veerdonk, met medewerking van Betty Litamahuputty, Hedendaags Javaans. Een leerboek (Leiden: Opleiding Talen en Culturen van Zuidoost-Azië en Oceanië, Universiteit Leiden, 2000) [Semaian 20], p. 31. 
situation, basa is spoken to express courtesy; the intermediate speech style is called basa madya.

TVRI Jogja chose basa as a result of a seminar it held to discuss which speech style should be used in its Javanese news programme.51 TVRI thought that Yogyakartans would not be willing to accept the use of ngoko in a television programme, as this style is only used to communicate with persons with whom one is familiar. ${ }^{52}$ The choice of basa might also have been influenced by the link between the image of the station and the court-related branding of Yogyakarta. Jogja TV possibly because of its connection to the kraton - also opted for the use of the polite speech style, to pay its audiences respect.

Although both these stations erred on the side of courtesy, the use of the familiar Javanese speech ngoko in news programmes did not have to be a hindrance to the viewers as proven by TATV's news broadcasts. Its morning news, Kabar Awan, and evening news, Kabar wengi, were presented in colloquial Javanese. Although the news topics were introduced in ngoko, the speech style for use in familiar circumstances, some of the discussions with audiences who called the station to air their comments and opinions were held in basa. TATV's daily evening bulletin, focusing on crime news in Surakarta, Yogyakarta and Magelang, used ngoko throughout the entire programme.

Every day at prime time, besides the morning and the afternoon news, presented in Javanese, Jogja TV broadcasts Pawartos Ngayogyakarta (Yogyakarta News). ${ }^{53}$ The television station categorises Pawartos Ngayogyakarta as soft news, as it presents items of human interest, local history, art and culture, and local events in an entertaining style. These items are alternated with advertisement blocks. Conversely, Jogja TV's local news programme in Indonesian, Seputar Jogja, is categorised as hard news, a formal offering of the latest updates on politics, economics and current affairs in Yogyakarta and its environs.

Pawartos Ngayogyakarta is presented by either a male or female newsreader, wearing an outfit inspired by traditional Javanese dress. It adheres to a fixed format that has remained unvaried for years. The presenter in the studio opens the programme, addressing the audiences with 'Salam Indonesia' (Hello Indonesia). This address, accentuated by the badge of the red-and-white Indonesian flag worn by the newsreaders, is designed to define the television station's branding; local wisdom is presented as part of the Indonesian identity. ${ }^{54}$ Pawartos Ngayogyakarta combines the polite speech style of Javanese with a swift and dynamic style of presentation, while the prosody follows a kind of international standard for the reading of news programmes, not formerly associated with the use of basa and/or traditional settings. During interviews, other speech styles are sometimes used, depending on the interlocutors. With a market-seller, for example, the reporter uses the intermediate speech style basa madya. Often the interviewees choose to speak Indonesian, usually with a strong Javanese accent. Possibly, the televised news is considered to be an official environment in which one is not used to speaking Javanese; at least not under the New Order. If Indonesian is spoken, the reporter at the locale summarises the interview in basa in the voice-over.

51 Personal communication, Agus Kismadi, July 2012.

52 Personal communication, RM Kristiadi, 23 Mar. 2009.

53 In 2009 prime time was at 19.30; in 2014-2015 at $19.00 \mathrm{hrs}$.

54 Personal communication, Oka Kusumayudha, 13 Mar. 2009. 
All Pawartos Ngayogyakarta programmes include a sequence called Awicarita, in which Javanese shadow puppet characters are introduced to the public in a wayang kulit-like setting, and every episode used to close with the sequence Pitutur, containing traditional Javanese teachings on cultural values and moral behaviour, presented in both Javanese and Indonesian. These sequences can be examined in a number of ways. Both Awicarita and Pitutur add a unique local cultural flavour to the news programmes. They refer to local traditional culture and a traditional Javanese method of instruction (piwulang) and confirm the link between Jogja TV and the kraton, the perceived icon of Javanese culture and centre of its preservation. Yet the inclusion of Awicarita and Pitutur can also be perceived as a continuation of the didactic character of New Order broadcasting.

Once it was relatively independent of the national TVRI station, and possibly inspired by the success of the other local stations, TVRI Jogja began broadcasting Yogyawarta, a 30-minute daily news programme in Javanese. It focuses on issues touching village life, farming, health and local culture. ${ }^{55}$ The local TVRI station also broadcasts Berita Jogja, a news programme in Indonesian focusing on the locality of Yogyakarta. Yogyawarta is presented in a formal style that differs little from the New Order-era news programmes and often still focuses on local government matters. As this station has built on the practices of its predecessor, TVRI Stasiun Yogyakarta, this is quite logical. Jogja TV has also adopted some of these characteristics, including the featuring of local ceremonial events and officials. ${ }^{56}$ Both Pawartos Ngayogyakarta and Yogyawarta present neutral reportage, meaning the television journalists offer 'a scripted explanatory and descriptive narrative voiced over edited material recorded by the camera man or woman at the scene of the event' ${ }^{57}$ Unscripted assessments, comments or critical reflections are excluded. ${ }^{58}$ But the use of Javanese, however formal, the more dynamic and personal delivery of the presenters who introduce themselves to the viewers, and the foregrounding of local issues all differentiate these news programmes from the national New Order-style bulletins.

Javanese content is not confined to that of Yogyakarta; (sub)cultures from its environs are not ignored. The programme Inyong Siaran, produced and broadcast by Jogja $\mathrm{TV}$, is a good example. It features news on socioeconomic topics, art and culture, tourist sites, and traditional food, presented in the Javanese dialect of Banyumas. The studio presentation alternates with relevant audiovisual footage, with voice-overs by local reporters and interviews with local people. The target audience for Inyong Siaran consists of students and other inhabitants of Yogyakarta from Banyumas, but the programme is also popular among other audiences who are attracted by the cadence of the dialect.

A closer look at these Javanese news programmes reveals a double 'vernacularization process'. ${ }^{59}$ Initially, the national television station adapted the global news

55 Personal communication, Agus Kismadi, June 2012.

56 Philip Kitley, 'New Order television rituals', in Images of Malay-Indonesian identity, ed. Michael Hitchcock and Victor T. King (Kuala Lumpur: Oxford University Press, 1997), pp. 236-64; and Kitley, Television, nation, and culture.

57 Paddy Scannell, 'Review essay: The liveness of broadcast talk', Journal of Communication 59, 4 (2009): E4.

58 Ibid.

59 Appadurai, Modernity at large, p. 102. 
format to local (Indonesian) situations. News broadcasts were characterised by their formal style of presentation, the use of the national language and a focus on matters Indonesian. They also had ceremonial content. After Reformasi and as soon as the construction of a regional autonomy began, local broadcasters moved away from the national news presented in Indonesian. How they localised the news was determined by their specific area of reach, including the use of local languages and choice of local topics and events, and by how they imagined their audiences. On the whole, their presentation style became less formal and more relaxed.

Language use in these news programmes can differ widely; it gives voice to subcultures and is no longer restricted to the cultures of the cities of Yogyakarta and Surakarta and the main dialect of their courts, which became the standard Javanese. By opting for a conservative choice in the use of formal Javanese, Jogja TV and TVRI Jogja have secured their status quo. Conversely, the Javanese used in TATV's Kabar Awan and Kabar Wengi reflects a trendy approach to the language, tailored to the dialects and styles used by local radio stations and in contemporary artistic performances, both live and mediatised.

\section{Talk shows}

Jogja TV's Pocung and TVRI Jogja's Karang Tumaritis, both live broadcasts, are examples of how the concept of a talk show is used to define, celebrate and defend the local. Both programmes are based on a similar formula: An interactive dialogue, hosted by a talk-show personality who discusses a topic with one or more specialists in the studio and answers phone calls from viewers at home. By raising issues related to local wisdom both television stations claim to preserve the refined cultural heritage of their ancestors that is considered relevant to contemporary, pluriform Yogyakarta. ${ }^{60}$

The title of the programme, Pocung, refers to a particular verse form in traditional Javanese poetry, tembang macapat, whereas Karang Tumaritis alludes to the natal village of Semar, the quintessential god and clown in the Javanese wayang. The leaders of Pocung and Karang Tumaritis frame the context - and thereby define the programme's identity - by using a combination of auditory and visual elements, all referring to aspects of so-called traditional Javanese culture, such as gamelan music (performed on the gamelan or a keyboard), shadow puppetry, literature and architecture.

Everything in Pocung - the setting, music, costumes and the formal language including the prosody, the presenters' body language and discussion style - offers a courtly image of Javanese culture, associated with being aristocratic, refined and learned. Javanese history, especially court history, cultural heritage and etiquette are discussed seriously, and supported by quotes from authorities. After the first slot with commercials, viewers throughout Yogyakarta and Surakarta phone in to ask questions; most of them use basa.

Karang Tumaritis is presented in the studio of TVRI Jogja, in a setting consisting of a mixture of traditional and modern elements. The atmosphere is less formal than that of Pocung, and the specialists wear a contemporary variant of the traditional costume. Yogyakartan culture is a major topic of discussion, as are 'tradition', the loss of 
tradition in contemporary Java, and the need to preserve it. Other topics include Javanese culture in general, Islam, and the younger generation(s). The show ends with announcements of forthcoming cultural performances, and a final message from Semar, in the guise of the reflective philosopher. Although the main presenter of the show consistently uses Javanese, the language of communication between the guests is mixed: Javanese in different speech styles - basa, madya and ngoko and sometimes Indonesian. This reflects the continuous code-switching that takes place in daily conversations between native speakers of Javanese in familiar circumstances. It seems that Indonesian is used as an escape valve when the speaker would automatically have tended to speak in the familiar ngoko, but in the televisual context - according to the etiquette adhered to by the programme participants this informal speech would be unacceptable. The programme's producer says that the purpose of this natural use of code-switching is to create a more egalitarian atmosphere than that of its predecessor, Pringgitan, in which the polite basa was used. ${ }^{61}$

The setting, topics, language use and musical intermissions are not the only parameters that define the degree of Javaneseness in these talk shows. Proximity and familiarity are important factors in determining the local character of the broadcasts. When callers state their name and locality, a link is created between the audiences at home and the 'actors' in the studio, between the broadcasting location and the callers' habitat. Hence, 'the relationship between spatial and virtual neighborhoods' is fairly close. ${ }^{62}$ Often, just as in radio programmes, interactive guests who call in are recognised by the presenter of the talk show, either upon hearing their name or just by the sound of their voice. This gives an idea of the popularity of the shows, and of their scope and reach. Conseqently, Bu Ayub from Kulonprogo and Pak Harjono from Plaosan play an important role in confirming the local character of Pocung and Karang Tumaritis.

\section{Featuring local cultural expressions}

A second strategy to localise television consists of featuring local cultural expressions in various forms and formats: Traditional performance genres (wayang kulit and kethoprak); new media formats based on local traditional performance genres (Obrolan Angkring); as well as hybrid genres categorised and/or perceived as traditional (the hybrid music genres campursari and pop Jawa). I will concentrate on examples of the first two categories.

\section{Traditional performance genres}

The presence of a large variety of cultural resources in Yogyakarta has offered the television industry enormous potential to be explored and transformed into interesting - and profitable - programmes. Like broadcasting institutions under the New Order, local television stations have disseminated Javanese performing arts genres that they categorise as traditional. However, to make these performances alluring to new, particularly younger, audiences, they have often been adapted. For

61 Personal communication, RM Kristiadi, Mar. 2009.

62 Appadurai, Modernity at large, p. 189. 
instance, Jogja TV has recorded night-long live wayang kulit performances and broadcast them daily in one-hourly episodes, to raise their appeal for younger audiences living in the outskirts of Yogyakarta. ${ }^{63}$

Since its foundation, TVRI Jogja had been broadcasting shadow puppet shows, either as transmissions of live performances recorded on location, or as studio performances attended by audiences, recorded and edited before transmission. The station continued its long-standing cooperation with other local media, the newspaper Kedaulatan Rakyat and the radio station RRI Yogyakarta, and with the Yogyakarta branch of the puppeteers' association Pepadi (Persatuan Pedalangan Indonesia) to transmit the wayang kulit performances from the kraton premises, the Sasana Hinggil Dwi Abad, every second Saturday of the month. ${ }^{64}$ These live transmissions were relayed by Jogja TV and RBTV. ${ }^{65}$ However, for budgetary reasons, TVRI Jogja stopped these regular broadcasts in 2011 for a while. Despite its lack of resources, it has continued to cooperate with local institutions and governments, which have organised occasional shadow puppet performances that are recorded and transmitted by the station. By collaborating with local communities, it has profited doubly. It has forged close contacts with the agents involved and obtained cheap local content.

All kinds of other local performance genres have featured at the local television stations. These opportunities give the stations grounds to claim they play an important role in preserving and developing traditional genres, and in supporting local performing artists. ${ }^{66}$ One item on the programme to celebrate Jogja TV's third anniversary in 2007 was a three-day horse-dance (jathilan), held on the northern kraton square. The programme attracted enormous attention from both potential festival participants and audiences. ${ }^{67}$ The station declared the purpose of the festival to nurture local culture (melestarikan kebudayaan lokal), particularly at the grassroots level, and to promote a folk genre (mengangkat seni kreasi rakyat) that was being neglected. Conforming to its motto, Jogja TV claimed to be countering the increasing presence of foreign cultural elements, said to exert an unmistakably malign influence on the survival of local cultures. In these statements, with its unremitting focus on the preserving of local culture and the warding off of external, potentially negative cultural influences, Jogja TV was aligning itself with New Order ideology and discourse. Fortuitously, this ideological stance also disguised the private broadcaster's use of local culture for commercial purposes.

63 Personal communication, Oka Kusumayudha, 13 Mar. 2009.

64 Joko Budhiarto/B. Murdoko, 'Sasana Hinggil Dwi Abad dan wayang kulit' [Sasana Hinggil Dwi Abad and wayang kulit], Kedaulatan Rakyat, 16 Oct. 2009.

65 Gatot Marsono, '24 Agustus 2009, TVRI 47 tahun; 2009 "tahun produksi", tiada hari tanpa produksi!' [24 Aug. 2009, TVRI is 47 years old; 2009 is "the year of productions", not a day without productions!], Kedaulatan Rakyat, 25 Aug. 2009.

66 Mawar Kusuma, 'Jogja TV: Tradisi tiada henti'.

67 Dude: 'Grup Jathilan dari Temanggung ramaikan festival jathilan' [Jathilan group from Temanggung liven up Jathilan Festival], GudegNet, 13 Nov. 2007; http://gudeg.net/id/news/ news/2007/11/3410/Grup-Jathilan-dari-Temanggung-Ramaikan-Festival-Jathilan.html (last accessed 2 May 2014); and several newspaper sources. 


\section{New media formats based on local traditional genres}

Local traditional performance genres have inspired the TV producers to create new television genres that in all their aspects - settings, actors, characters, topics, presentation, audiences and sponsors - cater to mediated Javaneseness. For various reasons, TVRI Jogja's Obrolan Angkring (Chatting at the Food Stall) is among the best received of these productions. Broadcast regularly since April 1997, it is one of the rare programmes able to bridge the transition from the New Order period to the Reformasi with all the concomitant changes in the Indonesian televisionscape. It features actual themes in a local setting. These are discussed humourously but critically in a familiar style of Javanese. The actors are trained in performing in Javanese for Javanese audiences; well-versed in Javanese jokes and puns, they act and improvise in a typically Javanese manner. The audiences, familiar with this kind of acting and joking, appreciate it highly. The setting refers to the Yogyakartan food stalls selling local specialties, where one enjoys a sociable evening with friends, talking and eating. Proximity is boosted by the participation of famous local artists, making the programme even more attractive, particularly to the public who attends the TVRI studio recordings. Once in a while, the programme is presented and recorded in iconic spaces, including the kraton. When Javanese dancer and comic Didik Nini Thowok was the guest star, for instance, the public flocked to the palace to see the show. ${ }^{68}$ The programme is sponsored by local entrepreneurs.

Those present in the TVRI studio during recordings are directly involved in the show in several ways. Their laughter at the jokes becomes part of the show; they participate in a lottery for the Obrolan Angkring T-shirt contest; and, at the end of the performance, the food is shared with the audience, making the 'common man [...] part of the event'. ${ }^{6}$

\section{Establishing local alliances}

A third strategy to localise television and represent the local is achieved by establishing alliances with local artists and audiences, enterprises and advertisers, local government and other institutions, production houses and so on. Popular dancers, musicians, theatre and television personalities are invited by local television stations to act as hosts and entertainers in their shows. The close-knit relationship between television and traditional performing artists has been influential in the survival of certain artistic genres.

'Live' contact with local communities is essential to these TV stations. Outside recordings and broadcasting from local landmarks encourage mutual identification and bonding, particularly when the public is involved in the programme. Another source of bonding are the off-air activities organised by the television stations, to celebrate the station's anniversary, for instance, or for charity. More recently, Facebook and other social media have begun to play an influential role in linking audiences to television stations and specific programmes.

68 I personally witnessed the recording of this episode on 5 Aug. 2001.

69 Judith Bosnak, 'Shaping the Javanese play: Improvisation of the script in theatre performance' $(\mathrm{PhD}$ diss., Leiden University, 2006), p. 110. 
Brian Moeran says that such activities reveal the inextricable link between the economic and cultural characteristics of the medium. ${ }^{70}$ By participating in and reporting on special events, television stations accumulate cultural and social capital. ${ }^{71} \mathrm{By}$ associating themselves with these events and their sponsors, and with the stars, artists and audiences involved, the stations 'create [their] own cultural logic and currency which can be converted by recognized rates of exchange into economic capital'. ${ }^{72}$

\section{Generating income and local content}

A lack of both funding and content are among the problems local television industries have to solve. An important source of income for the private stations is generated by advertisements placed by local and national enterprises. Initially, the local TV stations in Yogyakarta seemed to have difficulty in attracting local advertisers, but slowly their interest has increased. Understandably, in terms of income, impact and prestige, contracting national rather than local companies for the commercial slots was more rewarding. The sorts of products advertised in either local or localised commercials include tea and coffee, traditional medicine and traditional beauty products.

One strategy to generate income from local sponsors on a regular basis is to establish contracts with local government authorities, political parties and other institutions. The local authorities buy time slots and deliver content, and sometimes even audiences, leaving the television stations to organise the technical aspects of mediation and the actual broadcasts, often talk shows. Both TVRI Jogja and Jogja TV collaborate with local government in this way. TVRI Jogja has categorised these programmes as variety shows, but their real purpose is to communicate government policy and development programmes to the public. An example is TVRI Jogja's Taman Gabusan, a 'cooperation' with the government of the Bantul regency. In 2009, this weekly 30-minute programme was relayed by Jogja TV and RBTV. ${ }^{73}$ Also in 2009, Jogja TV broadcast Gardu Projotamansari, a 'cooperation' with the regional Bantul Representative Council (Dewan Perwakilan Rakyat Daerah, DPRD), which announced the programme on its website. ${ }^{74}$

TVRI Jogja's Pangkur Jenggleng is a good example of a programme that floats on an alliance with a local political party. Pangkur Jenggleng, categorised by TVRI as staged comedy, combines local entertainment with light discussions on a current social or cultural topic. The title refers to the Yogyakartan comedian Basiyo who became famous for his Pangkur Jenggleng, a comic performance of a traditional melody, pangkur, and his radio show. The programme features all kinds of traditional Javanese cultural expressions performed by local artists, that are linked to social happenings and current events in Javanese society. ${ }^{75}$ They use different styles of Javanese

70 Brian Moeran, 'Introduction: The field of Asian media productions', in Asian media productions, pp. 1-35. Moeran refers to Pierre Bourdieu, 'The production of belief: Contribution to an economy of symbolic goods' (1986).

71 Moeran, 'Introduction', pp. 29-30.

72 Ibid.

73 TVRI Jogja programme description 2012.

74 DPRD Kabupaten Bantul, http://dprd.bantulkab.go.id/ (last accessed Oct. 2015).

75 Personal communication, Heruwati, 11 July 2012. 
and mix Javanese with Indonesian. Each episode has two comedians and several guest stars, and features a story containing a comic dispute, a discussion on a cultural topic and a moral. The musical accompaniment is by the orchestra of the local radio station, the Karawitan RRI Yogyakarta. Sponsor Hanafi Rais (son of prominent politician Amien Rais), who usually attends the recordings, is regularly addressed during the programme. Several slots in the broadcast are filled with advertisements of local banks and catering facilities. The audiences are recruited from local Muslim communities, mosques and Quran classes. The majority are women, elderly men and children, all wearing the uniform of the group to which they belong. In 2009, the waiting list to attend the studio recording was one year. ${ }^{76}$

The programme was conceived in 2003. When Amien Rais, a former leader of Muhammadiyah and then chairman of the Partai Amanat Nasional (PAN; the National Mandate Party) was running for presidency, he needed local backing and proposed to TVRI Jogja that they make a joint programme featuring local culture. ${ }^{77}$ The cooperation was initially organised by the Pusat Informasi Amien Rais (PIAR), the Amien Rais Center, a Yogyakarta-based institution which has a strong Muslim background. Later it was taken over by the Hanafi Rais Center.

Various interpretations have been offered for the show's positive reception. Hanafi Rais (who ran in the local elections in 2011 but lost) said the success was attributable to the local, specifically Javanese performance genres. ${ }^{78}$ TVRI Jogja's head believed that the programme reveals the actual meaning of local strength and identity. ${ }^{79}$ Bondan Nusantara, a well-known Yogyakartan kethoprak scriptwriter, director and actor, thought most programmes persuaded television viewers to act as consumers. With Pangkur Jenggleng, TVRI Jogja offers the audiences space to gather in front of the stage, watch the performance and interact with the performers - just as they used to do at non-televised traditional performances. ${ }^{80}$

The alliance between TVRI Jogja as a public-service broadcaster and the Hanafi Rais Center as representative of a political party has elicited criticism from the public and the press. Hanafi Rais personally said he sponsored the show because he treasures traditional Javanese art, but, precisely because of his sponsorship, the neutrality of TVRI as a public-service broadcaster has been questioned. Under the New Order, the station offered Golkar, the government faction, support in its programming; now it has changed allegiance to a local political party. Although Hanafi Rais denied that his support of Pangkur Jenggleng was for purely electoral purposes, election campaigns were actually discussed in several broadcasts. ${ }^{81}$ Even more obviously, the Pangkur Jenggleng guest stars invited the studio audiences and

76 Personal communication, Heruwati, Mar. 2009.

77 Personal communication, R.M. Kristiadi, 27 June 2012.

78 Personal communication, Hanafi Rais, 2 July 2012.

79 'TVRI Yogya siap menjadi televisi pemerintah daerah' [TVRI Yogya is ready to become local government broadcaster], Kompas Cetak, 15 Sept. 2003.

80 Personal communication, Bondan Nusantara, 2 July 2012.

81 'Caleg Stres di Pangkur Jenggleng' [Stressed legislative election candidates in Pangkur Jenggleng], Kedaulatan Rakyat, 18 May 2009. 
those at home to support specific candidates in the Indonesian legislative and presidential elections. ${ }^{82}$

Pangkur Jenggleng exemplifies how televised Javanese performance genres play a role in 'negotiating local power, money and religion'. ${ }^{83}$ The public TV station has continued to stress the importance of independence and neutrality, declaring that it upheld its non-commercial character. Despite this claim, it has accommodated both a religiously inspired political ideology — via the PAN sponsorship - and advertorial messages in its commercial time-slots. Furthermore, although the legislative authorities did not seem to accept their responsibility to guard the station's public status, the KPI was powerless to take action.

Rachmah Ida perceives a mirroring in 'the pattern of local media corporations and their local political and economic roles' between the Soeharto and the post-Soeharto eras, a situation not confined to Indonesia. ${ }^{84}$ In their 2003 conclusion to a comparative review of regulatory spaces in Asia, the authors state that industry concerns dominate public interest concerns throughout the region and are assisted in doing so by a range of nationally differentiated modes of co-option and collusion between state authorities and domestic operators' ${ }^{85}$ Apart from some adjustments, this statement still stands. In the case of the local broadcasters, I would rather say that local industry and government concerns dominate public interest concerns, and modes of co-option and collusion take place at the level of local government authorities and operators.

Nevertheless, it is important not to shut our eyes to the artistic input that has managed to escape this generalising idea, or to the more varied and pluriform content that has been the positive result of the birth of this new local broadcasting industry.

\section{Representing Javanese cultures on local television}

The TV programmes discussed in this article show how the concept of the local has acquired meaning(s) in the practices of the television industries and the actual processes of mediation. The localising strategies discussed are not new, however. They had been successfully applied by TVRI's regional stations ever since they began broadcasting. The innovation is in terms of scale and the offering of more potential choices to local audiences.

Compared to the New Order televisionscape, the flourishing of local private stations has definitely led to a general diversification of commercial television networks in Indonesia. On a smaller, much more local level, it has also enabled another kind of diversification, making more space (and air-time) available for local content, local culture and vernaculars. In the Special Region of Yogyakarta this means that not only is 'Javanese' culture represented, but that Javanese culture from a smaller city such as Banyumas, for instance, with its own characteristics, dialect and so on is given

82 'Kenapa TVRI Jogja tidak netral?' [Why is TVRI Jogja not neutral?], blog post, Kompasiana, 25 June 2014, http://hiburan.kompasiana.com/televisi/2014/06/25/kenapa-tvri-jogja-tidak-netral-660596.html (last accessed Sept. 2015).

83 Martin Richter, 'Grounded cosmopolitans and the bureaucratic field: Musical performance at two Yogyakarta state institutions', Sojourn: Journal of Social Issues in Southeast Asia 21, 2 (2006): 188-9.

84 Ida, 'Reorganisation of media power', p. 21.

85 Kitley, 'Civil society in charge?', pp. 17-18. 
exposure. Whereas under the New Order government television promoted the building of a national identity and focused on the unity of the country, the nation and the national language, nowadays more attention is paid to diversity. ${ }^{86}$ Consequently, local broadcasts address and represent Javanese identities, rather than identity - the former idea of homogeneous local cultures has been cast aside. The larger frame of reference remains however the nation, Indonesia.

Although '[1] ocal identity is not established by the mere facts of proximity' ${ }^{87}$ the role of proximity in the cases discussed is undeniable. In terms of ideology and branding, the television institutions in Yogyakarta link themselves to an image of the city imbued with its connotative meanings. This image is a construct that seems to have become fairly fixed and stereotypical in the course of time. It is connected to a geographical and mental space, reinforced by romantic and nostalgic ideas. Proximity is present in alliances with local artists and audiences, the local administration and government institutions, and advertisers. Its influence is found in content, style of presentation and language use. The media is embedded in local society, proof that they are social institutions.

Technologically, although 'local' refers to the restricted area of reach, as required by the 2002 Broadcasting Law, local television stations often cover areas beyond the borders of these restricted territories. Moreover, the law does not regulate the complexities of modern broadcasting practices which flow from convergence and transnationalisation'.88 Although local television has unquestionably adopted several characteristics of radio, and the term 'narrowcasting' would be more pertinent to its practices than 'broadcasting', live-streaming and on-demand audiovisual media services have the opposite effect. These developments will stimulate us to reconsider the meaning of the local in more depth.

Although the televisual situation in Yogyakarta is very specific and cannot be generalised, it can be compared to television in other parts of Indonesia where similar processes are occurring. Despite their use of global technology and television formats and despite their commercial interests, local television stations are giving a much more diversified representation of local identity in their programmes than under the New Order regime and this development is acknowledged in contemporary public discourse led by local intellectuals.

Nevertheless, some critical comments are in order. After Sen and Hill had interviewed media workers and audiences in Yogyakarta in the 1990s, they concluded that 'neither saw their "locale" reflected in the nation's media' ${ }^{89}$ In my recent discussions with media workers, I discovered they felt their locale was reflected in the media, but not often enough and not yet as diversified in the full sense of the 2002 Broadcasting Law. After all, local content - relating to the locus of Yogyakarta and its cultures still makes up just a small percentage of the entire programming. Also, the

86 For a similar conclusion about 'the (re)presentation of regionalism in Indonesia radio', see Suryadi, 'Identity, media and the margins: Radio in Pekanbaru, Riau (Indonesia)', Journal of Southeast Asian Studies 36, 1 (2005): 150-51.

87 Webb Keane, 'Knowing one's place: National language and the idea of the local in eastern Indonesia', Cultural Anthropology 12, 1 (1997): 37.

88 Kitley, 'Civil society in charge?', p. 110.

89 Sen and Hill, Media, culture, and politics, p. 16. 
broadcasters have opted for local content that they presume will be most marketable to their audiences. Moreover, even after a decade the 2002 Broadcasting Law - licensing private TV stations to broadcast only locally - had not yet been fully implemented, meaning that 'the giants' in Jakarta were still broadcasting nationwide.

The new broadcasting legislation was intended to enforce diversity of content and ownership. Accordingly, the presence of new local stations has seen a significant increase in local content, offering more diversified kinds of news, information and entertainment. Importantly, language use is paid special attention. For the first time in the history of Indonesian television, the news is presented in the local vernacular, Javanese. Javanese is also used in a number of other broadcasts, new local media genres and all kinds of Javanese performance genres. Depending on the programme genre, the topic and the target audiences, multiple styles of Javanese are used, ranging from the very polite to the colloquial, and to mixtures of Javanese and Indonesian just as these occur in familiar conversations. Room is given to sociolects (such as youth language) and dialects (such as Banyumasan). By these actions, the television stations have enabled the diversification of Javanese in official contexts, away from the Central Javanese dialect that has long functioned as 'the' standard.

Viewed positively, local television in twenty-first century Indonesia has contributed to imbuing Javanese with a modern, lively and dynamic aura. In the words of Tom Hoogervorst, ${ }^{90}$ a 'defolklorization' of regional languages in the media has taken place. This development fits into the trend of an increasing use of Javanese in contemporary popular cultural expressions, like hip-hop and pop music. Nevertheless, it should be realised that broadcasts featuring Javanese performances remain marginal phenomena.

Whether the reorganisation of the Indonesian mediascape has actually provided all audiences in Indonesia with sufficient alternatives from which to choose still needs investigation. Real diversity of content is only available to those who have access to pay television and the Internet. The people who attend the recording of the TVRI Jogja programme Pangkur Jenggleng and afterwards watch the broadcast of this programme on television belong to the lower social strata and spend most of their lives in the same locale. Their economic and social circumstances preclude their access to cable television and the Internet, and therefore the chance of a proper choice.

Viewing local private television stations from the perspective of ownership and the networks to which they belong raises the question of whether the denomination 'local' is indeed applicable. The Bali Pos Media Group, owner of Jogja TV, for instance, is active in print media, radio and local television broadcasting in Bali and elsewhere in Indonesia (including Semarang TV in Central and Surabaya TV in East Java), and in non-media industries. As these media networks dominate information streams, how this affects the diversity of news content and how this dominance might influence the democratic calibre of the media should be investigated.

Other influences that should be appraised lie in the political and commercial spheres. After the passing of the Broadcasting Law, a public service broadcaster like the regional TVRI Jogja should be independent, neutral and non-commercial in

90 Tom Gunnar Hoogervorst, 'Basa Jawa Surabayaan: Describing Surabaya's linguistic ecology' (MPhil thesis, Leiden University, 2008), p. 72. 
character, providing services in the public interest, offering space for multicultural and pluriform contents. For budgetary, political and other reasons this has not happened. Sponsorship by local government - as in the case of Taman Gabusan and/or political parties - as in the case of Pangkur Jenggleng - does offer these institutions a platform. Like TVRI Jogja, Jogja TV has provided space for the messages of its local political allies, thereby restricting pluriformity, and approximating the character of New Order government television. Unquestionably, TVRI Jogja has acquired features of private television, allowing advertising in the commercial slots of its Javanese news programme, Yogyawarta, and other shows.

Initially, the branding of both broadcasters and much of their local programming was very similar. However, although Jogja TV has increasingly used local content for commercial reasons, TVRI Jogja has retained an interest in entertaining and informing local viewers for more ideological purposes. My conclusion is that local private and local public broadcasting services have interpreted and implemented the new legislation pragmatically. In doing so, they have both adopted each other's characteristics. 